\title{
Identification and field evaluation of a new blend of the sex pheromone of Hypsipyla grandella
}

\author{
Maria Carolina Blassioli-Moraes ${ }^{(1)}$, Miguel Borges ${ }^{(1)}$, Raul Alberto Laumann ${ }^{(1)}$, \\ Rafael Borges ${ }^{(2)}$, Amanda Rodrigues Viana ${ }^{(1)}$, Marcílio José Thomazini( ${ }^{(3)}$ Cleonor Cavalcante Alves Silva ${ }^{(1)}$, \\ Márcio Wandré Morais de Oliveira ${ }^{(1)}$ and Mari Ines Carissimi Boff(2)
}

\begin{abstract}
(1)Embrapa Recursos Genéticos e Biotecnologia, Parque Estação Biológica, W5 Norte (Final), Caixa Postal 02372, CEP 70770-917 Brasília, DF, Brazil. E-mail: carolina.blassioli@embrapa.br, miguel.borges@embrapa.br, raul.laumann@embrapa.br, amanda_2111@hotmail.com, rborges1977@hotmail.com, cleonor.silva@embrapa.br, márcio.wandre@embrapa.br (2)Universidade do Estado de Santa Catarina, Centro de Ciências Agroveterinárias, Departamento de Agronomia, Avenida Luiz de Camões, ㄲo 2.090, Conta Dinheiro, CEP 88520-000 Lages, SC, Brazil. E-mail: mari.boff@udesc.br ${ }^{(3)}$ Embrapa Florestas, Estrada da Ribeira, Km 111, Guaraituba, Caixa Postal 319, CEP 83411-000 Colombo, PR, Brazil. E-mail: marcilio.thomazini@embrapa.br
\end{abstract}

Abstract - The objective of this work was to identify and carry out a field testing of the sex pheromone composition of the mahogany shoot borer, Hypsipyla grandella, from a population in Southern Brazil. Abdominal glands of $H$. grandella females were excised and extracted using n-hexane; the gland extracts were analysed by gas chromatography (GC-FID and GC-MS). Wind-tunnel and electrophysiology experiments were conducted to evaluate the role of gland compounds in the mating behavior of $\mathrm{H}$. grandella males. In the field, pheromone traps containing the identified pheromone were tested. In addition to the two previously identified compounds - $(9 Z, 12 E)$-tetradecadien-1-ol and $(9 Z, 12 E)$-tetradecadienyl acetate -, in insects from Central America populations, two additional compounds were identified in the blend: (9Z)tetradecen-1-ol and (9Z)-tetradecenyl acetate. Gas chromatography-electroantennographic analyses showed that these four components elicited antennal responses from conspecific males. Wind tunnel bioassays using different amounts of the components Z9-14:OH, Z9,E12-14:OH, Z9-14:OAc, and Z9,E12-14:OAc, elicited male responses similar to the response to conspecific calling females. When the binary and quaternary mixtures were tested in field conditions, males were attracted to the traps containing the quaternary mixture. The new pheromone blend identified in $\mathrm{H}$. grandella males has a great potential to be exploited as a monitoring tool or control measure in the field.

Index terms: electroantennography, gland extract, mahogany shoot borer, pheromone redescription, semiochemical, wind tunnel bioassays.

\section{Identificação e avaliação em campo de uma nova mistura do feromônio sexual de Hypsipyla grandella}

Resumo - O objetivo deste trabalho foi identificar e testar em campo a composição do feromônio sexual da broca-do-ponteiro do mogno, Hypsipyla grandella, de uma população do Sul do Brasil. As glândulas abdominais de fêmeas de $H$. grandella foram excisadas e extraídas por meio de n-hexano; os extratos de glândula foram analisados por cromatografia gasosa (GC-FID e GC-MS). Experimentos de túnel de vento e eletrofisiologia foram conduzidos para avaliar o papel dos compostos das glândulas no comportamento de busca de acasalamento pelos machos de $H$. grandella. Armadilhas com o feromônio identificado foram testadas em campo. Além dos compostos previamente identificados - $(9 Z, 12 E)$-tetradecadien-1-ol e acetato de $(9 Z, 12 E)$-tetradecadienila -, em populações de insetos da América Central, dois novos compostos foram identificados: (9Z)-tetradecen-1-ol e acetato de (9Z)-tetradecenila. A análise eletroantenográfica mostrou que estes quatro compostos provocaram uma resposta da antena dos machos coespecíficos. Os bioensaios em túnel de vento - com misturas binária, ternária e quaternária, com uso de diferentes quantidades dos compostos - Z9-14:OH, Z9,E12-14:OH, Z9-14:OAc e Z9,E12-14:OAc -, mostraram uma resposta do macho similar à resposta de chamamento das fêmeas coespecíficas. Quando as misturas binária e quaternária foram testadas em condições de campo, os machos foram atraídos para as armadilhas com a mistura quaternária. A nova mistura feromonal identificada em machos de $H$. grandella tem grande potencial para ser usado no monitoramento e controle desta praga no campo.

Termos para indexação: eletroantenografia, extrato de glândula, broca-do-ponteiro do mogno, redescrição de feromônio, semioquímicos, bioensaios em túnel de vento. 


\section{Introduction}

In several parts of the world, the establishment and cultivation of high-value timber species of the Meliaceae family like Swietenia, Cedrela, Khaya, and Toona species have failed due the attack of the shoot borer moths, Hypsipyla spp. (Lepidoptera: Pyralidae), mainly $H$. grandella Zeller and $H$. robusta Moore (FAO, 2009; Plath et al., 2011). The larvae bore the terminal and lateral shoots, breaking the apical dominance, and producing stem ramifications, which can reduce the timber commercial value.

From the early 1970's through the 1990's, it is possible to find a number of studies with different approaches which aimed at controlling Hypsipyla spp., such as: the development of resistant cultivars; the use of mixed-species plantations to enhance the diversity of the plants, which can have negative effects on herbivorous by the reduction of the capacity to find host plants, and favors natural enemies, contributing to reduce pest population level; the biological control; the chemical control; the use of semiochemicals from meliaceous spp. that have a negative effect on Hypsipyla spp.; and the use of sex pheromones to control these pests (Assiri-Bosson \& Gallois, 1982; Borek et al., 1991; Goulet et al., 2005; Lago et al., 2006; Plath et al., 2011). However, despite all the efforts to manage these insects, they are still a limiting factor to the success of Meliaceae plantations.

From all these mentioned studies, there is a consensus that the control of Hypsipyla will be successful by the use of an integrated approach, or a strategy that involves the use of resistant cultivars, rational silvicultural practices, and control methods for the adult insect (Lunz et al., 2009; Plath et al., 2011). In general, Lepidoptera pests are efficiently monitored and, in some cases, they can be controlled using sex pheromone traps (Witzgall et al., 2010). Mainly for $H$. grandella, the use of sex pheromones to control adults might be the unique viable alternative for directly controlling this pest, since the larvae penetrate the stem or leaf midrib as soon as they hatch, which hinders the control. Some previous studies tried to identify the sex pheromone of the two main pests of the meliaceous species, Hypsipyla robusta and H. grandella (Assiri-Bosson \& Gallois 1982; Borek et al., 1991); however the identified blends in these works were not efficient to capture these moths under field conditions (Borek et al., 1991).
The objective of this work was to identify and carry out a field testing of the sex pheromone composition of the mahogany shoot borer, Hypsipyla grandella, from a population in Southern Brazil.

\section{Materials and Methods}

Hypsipyla grandella pupae were obtained from a laboratory colony maintained at Embrapa Floresta, in Colombo, PR, Brazil $\left(25^{\circ} 17^{\prime} \mathrm{S}, 4^{\circ} 13^{\prime} \mathrm{W}\right)$. The laboratory experiments were conducted during 2011 and 2012. Pupae were sexed and placed inside $3 \mathrm{~L}$ plastic containers. The adults fed a sugar solution with 1,000 $\mathrm{mL}$ water, $50 \mathrm{~g}$ honey, $50 \mathrm{~g}$ sugar, $1 \mathrm{mg}$ Nipagin, and $1 \mathrm{mg}$ ascorbic acid, according to the methodology by Schmidt et al. (2001). Males and females were kept separately. For the bioassays, insects within the period of 24 to 72 hours after last molting were used. All insects were reared in acclimatized chambers with a reversed light: dark (L:D) cycle, and a 12:12 L:D photoperiod at $25 \pm 1^{\circ} \mathrm{C}$, and $65 \pm 2 \% \mathrm{RH}$.

Sex pheromone glands were extracted from one to three-day-old virgin calling females. The gland was forced to extrusion through a gentle pressure at the tip of the abdomen; by using a small spring scissor (model 15003-08, FST- Canada), the glands were excised, and placed into a $0.5 \mathrm{~mL}$ conical vial containing $100 \mu \mathrm{L}$ of hexane, and two to seven glands in each extract $(n=6)$. Gland contents were extracted for $20 \mathrm{~min}$; the extract was filtered using glass wool to remove solid residues and, then, it was concentrated to $50 \mu \mathrm{L}$ under a pure $\mathrm{N}_{2}$ flow. The extracts were stored at $-20^{\circ} \mathrm{C}$ until use.

The gland extracts were analysed by a gas chromatoghraph GC-FID Agilent 7890A, DB-5MS column, 60x0.32 mm ID, $0.25 \mu \mathrm{m}$ film (Supelco, Bellefonte, PA, USA), with the oven temperature maintained at $50^{\circ} \mathrm{C}$ for $2 \mathrm{~min}$, then increased at $5^{\circ} \mathrm{C} \mathrm{min}^{-1}$ to $180^{\circ} \mathrm{C}$ for $0.1 \mathrm{~min}$, followed by a gradual increase of $10^{\circ} \mathrm{C} \mathrm{min}^{-1}$ to $250^{\circ} \mathrm{C}$ for $20 \mathrm{~min}$. The column effluent was analysed with a flame ionization detector (FID) at $270^{\circ} \mathrm{C}$. One microliter of each sample was injected in splitless mode with helium as carrier gas. The samples were also analysed using a DB-WAX column, and they were also subjected to the same temperature programs and flow conditions, in order to calculate the retention index (RI) of each compound. The data were collected with EZChrom Elite software and handled using Excel (Microsoft Office 2007, Microsoft Corporation, USA). 
For the compound identification, selected extracts were analysed using an Agilent 5975C quadruple mass spectrometer, equipped with a DB-5MS column of 30x0.25 mm ID, $0.25 \mu \mathrm{m}$ film (Supelco, Bellefonte, PA, USA), and a splitless injector, with helium as carrier gas. Ionization was achieved by electron impact $\left(70 \mathrm{eV}\right.$, source temperature $200^{\circ} \mathrm{C}$ ), and the data were collected with ChemStation software. Identifications were made by comparison of spectra with library databases (NIST, 2008), or with published spectra, and using retention indices (El-Sayed, 2014; NIST..., 2016), and confirmed by GC co-injection using authentic standards. The quantitation of the sex pheromone components was conducted using the internal standard (IS) method, with n-tetradecane as IS.

Gas chromatography-electroantennographic detection (GC-EAD) was used to determine the compounds within mixtures that were detected by the male antennae. Analyses were conducted following the same procedures described by Blassioli-Moraes et al. (2016). The GC was equipped with a DB-5 column of $30 \times 0.25 \mathrm{~mm}$ ID, $0.25 \mu \mathrm{m}$ film (J\&W Scientific, Folsom, CA, USA), and a splitless injector with helium as the carrier gas $\left(1 \mathrm{~mL} \mathrm{~min}^{-1}\right)$. The oven temperature was programmed to $50^{\circ} \mathrm{C}(2 \mathrm{~min})$, then rised to $250^{\circ} \mathrm{C}$ at $15^{\circ} \mathrm{C} \mathrm{min}-1$, and kept at this temperature for $10 \mathrm{~min}$. Preparations were done in a continuous humidified air flow $\left(1 \mathrm{~L} \mathrm{~min}^{-1}\right)$ with a Stimulus Controller CS-55 detector (Syntech Inc., Hilversum, The Netherlands). Antennae of $H$. grandella males were tested using conspecific female gland extracts $(\mathrm{n}=5)$. Antennae of $H$. grandella males were also tested with synthetic solutions containing the four identified compounds - $\quad(9 Z, 12 E)$-tetradecadien-1-ol $\quad(Z 9, E 12-14: \mathrm{OH})$, $(9 Z, 12 E)$-tetradecadienyl acetate (Z9,E12-14:OAc), (9Z)-tetradecen-1-ol (Z9-14:OH), and (9Z)-tetradecenyl acetate (Z9-14:OAc). A single antennal preparation was used for only one chromatography analysis.

The n-hexane compounds for HPLC $(\geqslant 97 \%$ and redistilled) and n-pentane for HPLC ( $\geqslant 99 \%$ ), and n-tetracosane for GC ( $>99 \%)$ were purchased from Sigma Aldrich (Steinheim, Germany). Z9,E12-14:OAc (97\%) and Z9-14:OAc (99\%) were purchased from Bedoukian Research Inc. (Danbury, CO, USA). Z914:OH and Z9,E12-14:OH were obtained by alkaline hydrolysis; their respective acetates were dissolved in $4 \mathrm{~mL}$ ethanol, and $2 \mathrm{~mL}$ of $10 \%$ sodium hydroxide solution was added. The reaction was kept under reflux for 1 hour. The solution was then neutralized with hydrochloric acid, the organic phase was extracted using dichloromethane, and dried using magnesium sulphate. After solvent evaporation, the obtained compounds were used without further purification. Purity and structural confirmation of the chemicals were obtained by GC-FID, RMN, and GC-MS analysis. $Z 9-14 \mathrm{OH}$ and $Z 9, E 12-14: \mathrm{OH}$ showed the high purity of the obtained compounds, confirmed by GC-FID and GC-MS analysis, as follows: Z9-14OH (98.7 \% purity) ${ }^{1} \mathrm{H}$ NMR (300 MHz, $\left.\mathrm{CDCl}_{3}\right) \delta 0.89$ (t, $\left.3 \mathrm{H} J=6.9, \mathrm{CH}_{3}\right), 1.30\left(\mathrm{~b}, 14 \mathrm{H}, \mathrm{CH}_{2}\right), 1.56\left(\mathrm{~m}, 3 \mathrm{H}, \mathrm{CH}_{2}\right.$ $+\mathrm{OH}), 2.00\left(\mathrm{~m}, 4 \mathrm{H}, \mathrm{CH}_{2}\right), 2.71\left(\mathrm{~m}, 2 \mathrm{H}, \mathrm{CH}_{2}\right), 3.63(\mathrm{t}$, $\left.2 \mathrm{H} J=6.6, \mathrm{OCH}_{2}\right), 5.34(\mathrm{~m}, 2 \mathrm{H}, \mathrm{CH}=) \mathrm{MS}(70 \mathrm{eV}): \mathrm{m} / \mathrm{z}$ (abundance) 41 (53); 55 (100), 67 (72), 68 (45); 69 (45); 81 (69); 82 (76); 95 (49), 96 (49); 109 (21); 111 (19); 123 (9); 124 (7); 137 (4), 138 (4); 166 (2); 194 (7), 212 (0.2), and for Z9,E12-14:OH (99\% of purity) ${ }^{1} \mathrm{H}$ NMR (300 $\left.\mathrm{MHz}, \mathrm{CDCl}_{3}\right) \delta 1.30\left(\mathrm{~b}, 10 \mathrm{H}, \mathrm{CH}_{2}\right), 1.50-1.61(\mathrm{~m}, 5 \mathrm{H}$, $\mathrm{CH}_{2}$ ), 1.65 (d, $3 \mathrm{H}, J=4.71, \mathrm{CH}_{3}$ ), 2.01 (q, $2 \mathrm{H}, J=6.42$, $\left.\mathrm{CH}_{2}\right), 2.71\left(\mathrm{~m}, 2 \mathrm{H}, \mathrm{CH}_{2}\right), 3.63$ (t, $2 \mathrm{H} J=6.5, \mathrm{OCH}_{2}$ ), $5.39(\mathrm{~m}, 4 \mathrm{H}, \mathrm{CH}=) \mathrm{MS}(70 \mathrm{eV}): \mathrm{m} / \mathrm{z}$ (abundance) 41 (37); 55 (81), 67 (92), 68 (100); 79 (53); 81 (84); 82 (56); 95 (47), 96 (22); 107 (8); 109 (10); 121 (10); 123 (9); 135 (6), 149 (3); 192 (0.1); 210 (1.3).

Behavioral bioassays were conducted in a wind tunnel described in Blassioli-Moraes et al. (2016). Bioassays with $H$. grandella males were conducted using $0.5 \mathrm{~m} \mathrm{~s}^{-1}$ airflow. Treatments were spotted on $1.5 \mathrm{~cm}$ long and $0.5 \mathrm{~cm}$ wide filter paper strips (Whatman $\mathrm{N}^{\circ} 1$ ), which were placed inside a metal cage (2-4 mesh). The cage was placed on a support $15 \mathrm{~cm}$ above the wind tunnel floor, and $30 \mathrm{~cm}$ from the upwind end of the tunnel. Males were released individually and, before testing, they were allowed to acclimate for $5 \mathrm{~min}$ inside the wind tunnel. In the first set of the bioassay, male responses were evaluated with the odour released by five conspecific calling females. In the second set of the bioassay, $H$. grandella male responses were evaluated with synthetic solutions containing the four identified compounds in the $H$. grandella female gland extracts: two binary blends named mix-1 - Z9,E12-14:OH and Z9,E12-14:OAc -, at $0.075 \mu \mathrm{g}$ each, and mix-2 - Z9,E12-14:OH and $Z 9, E 12-14: O A c-$, at $0.05 \mu \mathrm{g}$ each; one ternary mixture, named mix-3, containing Z9-14:OH, Z9,E12-14:OH and Z9,E12-14:OAc, at 0.05:0.05:0.025 $\mu \mathrm{g}$; and two quaternary mixtures, named mix-4 $-Z 9-14: \mathrm{OH}$,

Pesq. agropec. bras., Brasília, v.52, n.11, p.977-986, nov. 2017 DOI: 10.1590/S0100-204X2017001100003 
Z9,E12-14:OH, Z9-14:OAc, and Z9,E12-14:OAc -, using a similar ratio that was quantified from the gland extract (0.27:1:0.05:0.2 $\mu \mathrm{g}$ ), and mix-5 - Z9-14:OH, Z9,E12-14:OH, Z9-14:OAc and Z9,E12-14:OAc-, at 0.05 $\mu \mathrm{g}$ each compound. All bioassays were conducted in a dark room, using a red light (Sollar Light, 21W Energy Saver), at $27^{\circ} \mathrm{C}$ and $65 \%$ of relative humidity. For each treatment, 30 replicates were carried out, and males were used only once. All bioassays were conducted from 6 to 9 hours, since scotophase initiation (Holsten $\&$ Gara, 1977). For the statistical analyses, only males that were capable of flying were ranked for: males that flew up wind, but did not show a mating behavior; and males that flew up wind, and showed mating behavior displays. Mating behavior displays were pre-defined as: antenna movements (up and down), flying in a zigzag manner towards the odour source, and exposition of male genitalia. Each observation lasted for $5 \mathrm{~min}$, after which males were removed.

Field trials were carried out as follows: in the municipality of Fraiburgo $\left(27^{\circ} 01^{\prime} \mathrm{S}, 50^{\circ} 55^{\prime} \mathrm{W}\right), \mathrm{SC}$, Brazil, from January to March 2012, and from January to March 2014; and in the municipality of Garça $\left(22^{\circ} 12^{\prime} \mathrm{S}, 4^{\circ} 39^{\prime} \mathrm{W}\right)$, SP, Brazil, from October to November 2013.

The field trial conducted in Fraiburgo evaluated three different treatments ( $\mathrm{n}=3$ for each treatment), as follows: A, grey rubber septum impregnated with pentane; B, a lure impregnated with $0.5 \mathrm{mg}$ of Z914:OAc:Z9,E12-14:OAc at 1:1 from ISCA Techonologia; and $\mathrm{C}$, grey rubber septa $(11 \mathrm{~mm})$ impregnated with $1 \mathrm{mg}$ of Z9-14:OH, Z9,E12-14:OH, Z9-14:OAc and $Z 9 E 12-14: O A c$, at the same ratio quantified from the female gland extracts. Each treatment was placed inside Delta traps (AR905-Plastic Delta traps, Isca Technologia), which were distributed in a completely randomized design, spaced $50 \mathrm{~m}$ from each other.

The experiment conducted in 2012 was placed in a 1.2 ha area with one-year-old Cedrela fisillis trees and, in 2014, the experiment was carried out in an area of 3.4 ha with three-year-old $C$. fisillis trees. The traps were hung up at $1.80 \mathrm{~m}$ above the ground, and they were examined once a week. In each survey date, the traps were redistributed with a new randomization, in order to avoid position bias. In the field trial, which was conducted in Garça, SP, Brazil, only two of the previous treatments were evaluated $(n=5$ for each treatment): treatment $\mathrm{A}$ and treatment $\mathrm{C}$.
Treatment B, which contained only two pheromone components, was not used because the preliminary results obtained in Fraiburgo in 2012 showed a low capture of insects compared to the lure containing the four components. The traps were set in a completely randomized design, in a 5.5 ha area within a Swietenia macrophylla plantation of one-to-eight-year-old trees. The traps were placed 1.50 to $1.70 \mathrm{~m}$ above the ground, with $100 \mathrm{~m}$ of distance between them, and they were evaluated at the end of the field test 28 days later. To prepare the treatment $\mathrm{C}$, rubber septa were impregnated following the methodology described by Aldrich et al. (2006). The septa were impregnated with $1 \mathrm{mg}$ of the synthetic pheromones Z9-14:OH, Z9,E1214:OH, Z9-14:OAc and Z9,E12-14:OAc, at the same ratio between the components quantified from female gland extract. The statistical analyses were performed with R 3.0.1 (R Core Team, 2012). Data from the wind tunnel bioassays were analysed by a GLM with a binomial distribution. The proportion and confidence interval $(95 \%)$ of responding insects to each treatment were also calculated. Data from the field experiment were analysed using a GLM model, with Poisson distribution of error, and the deviance analysis with $95 \%$ of confidence errors level, using the number of insects per trap as dependent variable, and treatment as fixed effect. The mean number of insects captured by treatment was compared by contrast analysis.

\section{Results and Discussion}

The chemical analyses of gland extracts of $H$. grandella females showed the presence of four peaks consistently present in the chromatograms: (9Z)-tetradecen-1-ol $\quad(Z 9-14: \mathrm{OH}) \quad(1), \quad(9 Z, 12 E)-$ tetradecadien-1-ol $\quad(Z 9, E 12-14: \mathrm{OH}) \quad(2) \quad(9 Z)-$ tetradecenyl acetate (Z9-14:OAC) (4) and $(9 Z, 12 E)$ tetradecadienyl acetate (Z9,E12-14:OAc) (6), and two minor peaks that were occasionally present in the samples (Table 1, and Figure 1). The four major compounds are common in sex pheromones of several other families of Lepidoptera (Acín et al., 2010). The mass spectra and the RI calculates of these compounds suggest that they could be $(9 Z, 12 Z)-9,12$-tetradecadien1-ol (Z9,Z12-14:OH) (3), and (9Z,12Z)-tetradecadienyl acetate $(Z 9, Z 12-14: O A c)(7)$ (Figure 1). The authentic standards of these compounds were not available for this study to confirm the identification; therefore, 
the calculation of the retention index on DB-WAX column and the co-injection were not conducted for these compounds. The co-injection of the synthetic compounds with the female extracts and GC peak enhancement confirmed the identities of the four major peaks (Figure 2). The ratio of the components Z914:OH, Z9,E12-14:OH, Z9-14:OAc, and Z9E12-14:OAc averaged 0.27:1:0.05:0.2 (Table 1). The compounds Z9,Z12-14:OH and Z9,Z12-14:OAc could be byproducts of pheromone biosynthesis (Jurenka, 2004), since there was no response of male antennae to these compounds. In a coupled GC-electroantennography, $H$. grandella male antennae responded to $\mathrm{Z} 9-14 \mathrm{OH}$, $Z 9, E 12: 14: \mathrm{OH}, Z 9-14: \mathrm{OAc}$, and Z9,E12-14:OAc, from

Table 1. Compounds identified in gland extracts of Hypsipyla grandella females ${ }^{(1)}$, average amount \pm standard deviation per gland, and retention index calculated using DB-5MS and DB-Wax column.

\begin{tabular}{lccc}
\hline Compound & $\begin{array}{c}\text { Amount per gland } \\
(\mathrm{ng})\end{array}$ & \multicolumn{2}{c}{ Retention index } \\
\cline { 3 - 4 } & $6.82 \pm 3.79$ & 1664 & DB-WMS \\
\hline$Z 9-14: \mathrm{OH}$ & $25.88 \pm 12.22$ & 1675 & 2239 \\
$Z 9 E 12-14: \mathrm{OH}$ & traces & 1686 & 2314 \\
$Z 9 E 12-14: \mathrm{OH}$ & $1.43 \pm 1.31$ & 1795 & - \\
$Z 9-14: \mathrm{OAc}$ & $4.57 \pm 2.00$ & 1805 & 2144 \\
$Z 9 E 12-14: O A c$ & traces & 1816 & 2233 \\
$Z 9 Z 12-14: O A c$ & &
\end{tabular}

${ }^{(1)}$ Volatiles were collected from 7 to 10 females for each replicate $(\mathrm{n}=5)$. the gland extracts of $H$. grandella females (Figure 3 A). It is interesting to notice, that even for very small amounts of the components Z9-14:OAc and Z9,E1214:OAc, the male antennae showed a clear response of depolarization-polarization to these compounds. However, there is no response to the compounds Z9,Z12-14:OH and Z9,Z12-14:OAc, which could indicate that they do not play a function as sexual attractant, but they might play an important cue to other moths to discriminate species. However, since the antennae response is dose-dependent (Rouyar

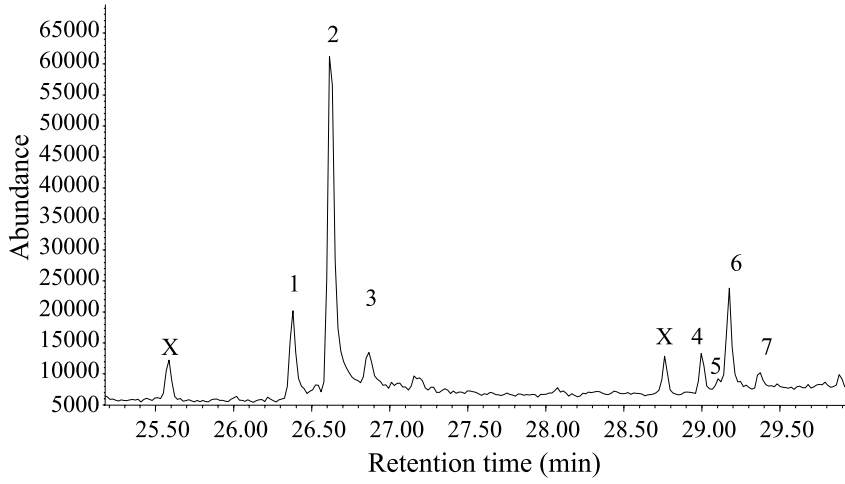

Figure 1. Chromatogram profile from GC-MS obtained from a gland extract containing eight glands of Hypsipyla grandella females . 1, Z9-14:OH; 2, Z9E12-14:OH; 3, Z9Z1214:OH; 4, Z9-14:OAc; 5, n-octadecane; 6, Z9E12-14:OAc, and 7, Z9Z12-14:OAc. X, contaminant peak.
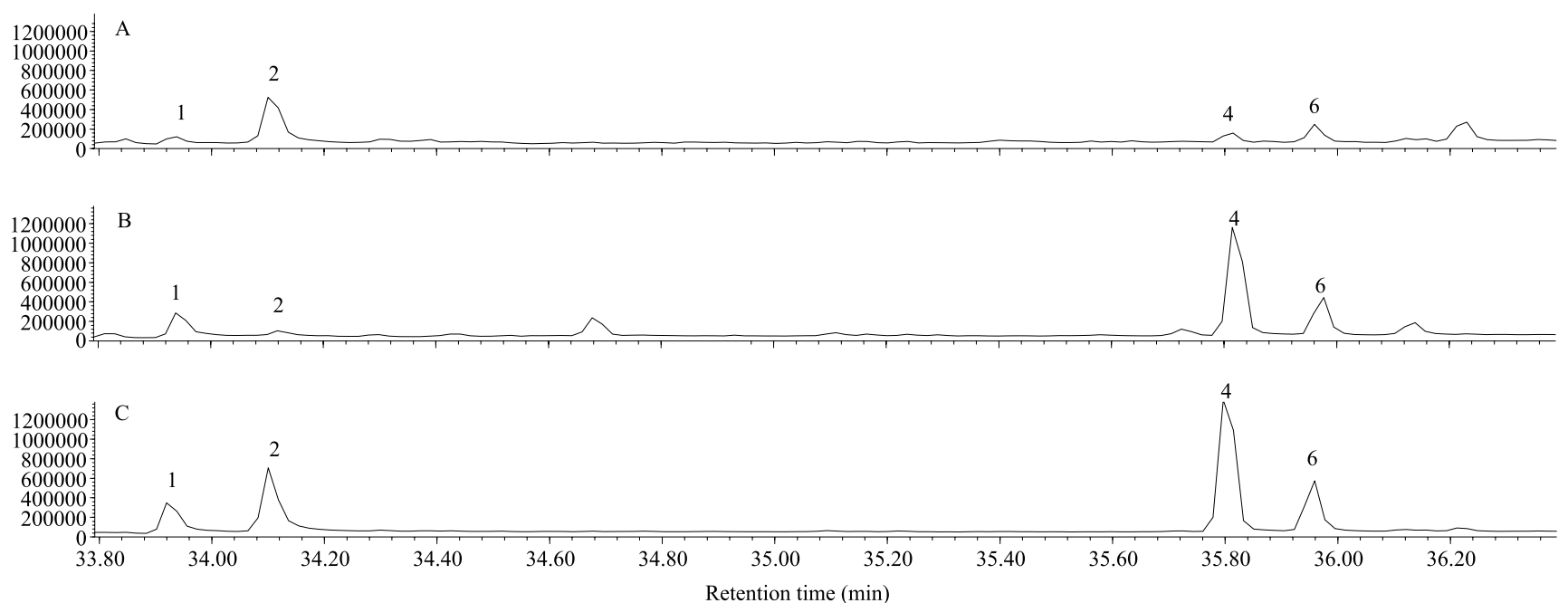

Figure 2. Chromatographic profile of A, female gland extracts; B, synthetic solution containing the four components (1, Z9-14:OH; 2, Z9E12-14:OH; 4, Z9-14:OAc; 6, Z9E12-14:OAc); and C, co-injection of a synthetic solution with female gland extract. 
et al., 2015; Badeke et al., 2016), further studies are necessary to verify this hypothesis. In the wind tunnel bioassays, the conspecific calling females used as odour source stimulated $42.8 \%$ of $H$. grandella males to display the reproductive behaviour, which consisted of antennation, genital exposure, and zig-zag flights towards the odour source; however, none of the tested males landed on the odour source (Figure 4). Therefore, a positive response was considered whether the tested males displayed reproductive behaviour and fly in direction to odour source. When stimulated with semiochemicals from plants or insects pheromones, both males and females present different behaviour patterns, like oriented flight, antennation, and genital exposure (von Arx et al., 2011). In the present study, $H$. grandella males, stimulated with gland female extract and synthetic mixtures of the sex pheromone, changed their foraging behaviour. The wind tunnel bioassays with males of $H$. grandella with the synthetic compounds identified in the conspecific female gland extracts induced the attraction of males to the odour source. When a binary mix containing Z9,E12-14:OH and $Z 9, E 12-14$ :OAc at $0.075 \mu \mathrm{g}$ (mix-1) was tested, $50 \%$ of males were induced to display mating behaviour. Mix-2 with the same ratio of these two components, but at lower amounts than mix-2 $(0.05 \mu \mathrm{g})$, elicited responses in $48.5 \%$ of males. Mix-3 with the three components Z9-14:OH; Z9,E12-14:OH and Z9-14:OAc at $0.05: 0.05 .0 .025 \mu \mathrm{g}$ for each compound, respectively, induced responses in $59.6 \%$ of the $H$. grandella males. Mix-4 containing the four compounds Z9-14:OH; Z9,E12-14:OH; Z9-14:OAc, and Z9,E12-14:OAc, at 0.27:1:0.05:0.2 $\mu \mathrm{g}$ for each compound, respectively, induced $61 \%$ of males to display mating behaviour. And a mixture containing the four compounds with $0.05 \mu \mathrm{g}$ of each component induced $76.9 \%$ of $\mathrm{H}$. grandella males to display mating behaviour (Figure 4). Results show that in wind tunnel bioassays $H$. grandella males showed a higher-response level, when evaluated with synthetic solutions than when they were stimulated with calling live females. In general, the blends of female gland extracts of Lepidoptera from different families present redundancy in chemical composition, that is, there are some compounds that provide the same information (Bruce \& Pickett, 2011). Therefore, these compounds can be removed from the blend without negatively or positively interfering on the male attraction (Bruce et al., 2010; Bruce \& Pickett, 2011). For instance, in the female gland extracts of Trichoplusia ni Hübner (Lepidoptera:Noctuidae), six

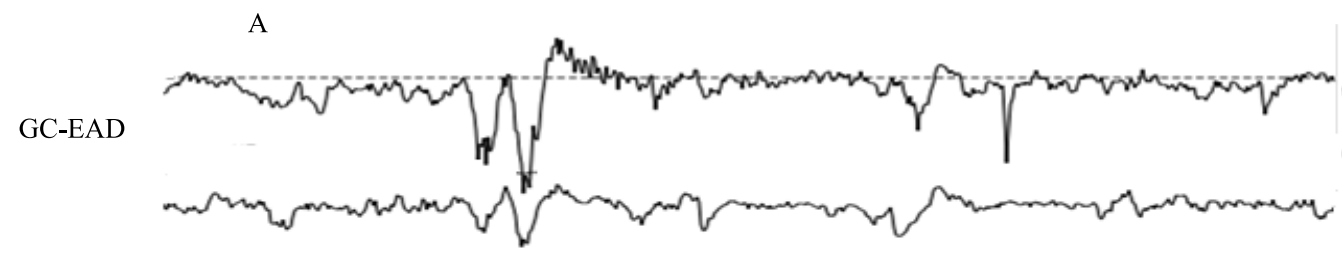

GC-FID



B

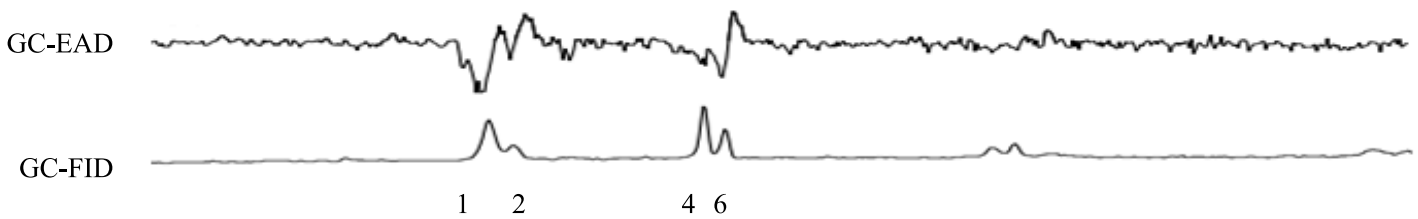

Figure 3. A, coupled gas chromatography-eletroantennogram (GC-EAD) of two male antennae of Hypsipyla grandella to gland extracts; and B, male antenna of $H$. grandella responding to a synthetic solution containing the four compounds: 1 , Z9-14:OH; 2, Z9,E12-14:OH, 3, Z9-14:OAc; and 4, Z9E12-14:OAc 
components were identified, all of them are involved in the sex pheromone communication system of T. $n i$; however, when tested blends of five or four components were used as odour source, $T$. $n i$ males showed an analogous response level to those observed with six components blends (Linn Jr. et al., 1984). Similar results were found in other populations of Neotropical lepidopterans, as follows: Spodoptera frugiperda Smith (Lepidoptera: Noctuidae), with eight compounds in sex pheromone blends, three of which are attractive to males (Batista-Pereira et al., 2006); Spodoptera eridania Cramer, with five compounds in sex pheromone blends, four of which are attractive to males (Teal et al., 1985); Elasmopalpus lignosellus Zeller (Lepidoptera: Pyralidae), with 10 compounds in sex pheromone blends, four of which are attractive to males (Lynch et al., 1984); and S. cosmioides (Walk.) (Lepidoptera:Noctuidae), with seven compounds in sex pheromone blends, two of which are attractive to males (Blassioli-Moraes et al., 2016). In gland extracts of $H$. grandella females, six compounds were identified and, similarly to other moths, not all compounds appear to be necessary to elicit reproductive behaviour of conspecific males (Byers, 2013).

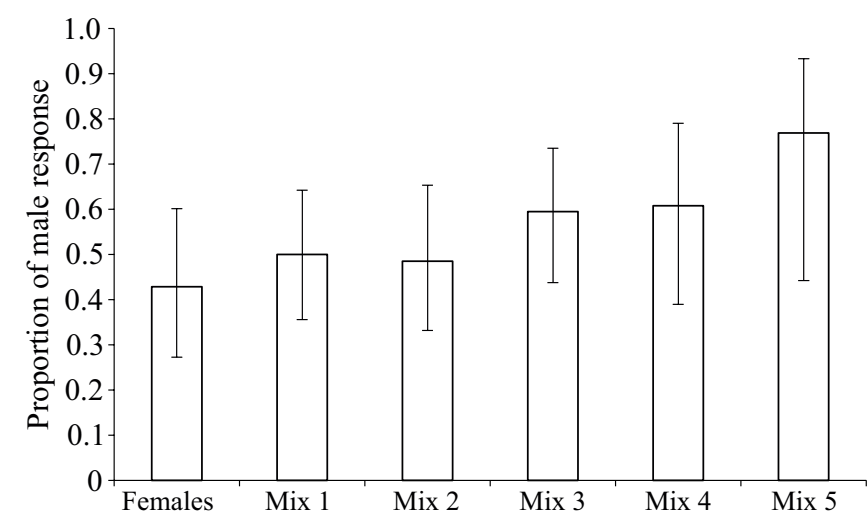

Figure 4. Proportion of male responses, in wind tunnel bioassays, for five females of Hypsipyla grandella, and for synthetic solutions. Mix-1, Z9,E12-14:OH and $Z 9, E 12-14: O A c$, at $0.075 \mu \mathrm{g}$ each; mix-2, Z9,E12-14:OH and $Z 9, E 12-14: O A c$, at $0.05 \mu \mathrm{g}$ each; a ternary blend, mix3 , containing $Z 9, E 12-14: \mathrm{OH}, Z 9, E 12-14: \mathrm{OH}$ and $Z 9, E 12-$ 14:OAC, at 0.05:0.05:0.025 $\mu \mathrm{g}$; and two quaternary blends, mix-4 with Z9-14:OH, Z9,E12-14:OH, Z9-14:OAc, and $Z 9, E 12-14: O A c(2.7: 10: 0.02: 0.6 \mu \mathrm{g})$, and mix-5, with $Z 9$ 14:OH, Z9,E12-14:OH, Z9-14:OAc, and Z9,E12-14:OAc, at $0.05 \mu \mathrm{g}$ each compound. Error bars show $95 \%$ confidence interval.
Previous studies partially identified the pheromone blend of $H$. grandella. Borek et al (1991) worked with a population from Matanzas (Cuba), and identified three components from female gland extracts: Z9,E12-14:OH, Z3-16:OAc, and 16:OAc. The compounds Z3-16:OAc and 16:OAc were not identified in gland extracts obtained from $H$. grandella females in the present study. These different blends identified in populations from Cuba and Brazil might indicate specific geographic sex pheromone blends originated by reproductive isolation of $H$. grandella, as it has been shown for other Lepidoptera, when geographical isolation conduced to variance of sex pheromone blends (Groot et al., 2009).

In the present study, three different treatments were tested in two field experiments, in Fraiburgo, SC, and one field experiment in Garça, SP, Brazil. In all fields, the treatment C (Z9-14:OH, Z9, E12-14:OH, Z914:OAc and Z9E12-14:OAc), with the four compounds, captured a higher number of $H$. grandella males than the other treatments, corroborating the results obtained in the wind tunnel bioassays. Over the three weeks of the first experiment conducted in Fraiburgo, 16 males of $H$. grandella were trapped in treatment $\mathrm{C}$. The GLM and contrast analysis showed that the capture was different between the traps of different treatments $(\mathrm{t}=35.15, \mathrm{df}=2, \mathrm{p}<0.001)$ (Figure $5 \mathrm{~A})$. The septum impregnated with two components, and the control septum impregnated only with hexane did not capture any insect. In 2014, the second field test, conducted in Fraiburgo during fifteen weeks, captured 52 males of $H$. grandella in the treatment $\mathrm{C}$, and 19 males in treatment B (Z9-14:OAc:Z9,E12-14:OAc), with the two major compounds; the septum impregnated with solvent did not capture $H$. grandella males. The effect of treatments on the captures $\left(\chi^{2}=73.52 \mathrm{df}=\right.$ $2, \mathrm{p}<0.001$ ) (Figure $5 \mathrm{~A}$ ) and the contrast analysis showed differences between the treatments $\mathrm{C}$ and $\mathrm{B}$ $\left(\chi^{2}=3.76, \mathrm{df}=93, \mathrm{p}=0.0003\right)$. The higher efficiency of the four component blends could be explained because the major components are used by male moths at a long distance, and generate an initial attraction response in males, while minor components should play a role in approaches and courtship (Zhang et al., 2012). In the field experiment set in Garça, SP, Brazil, the traps containing the four compounds captured 10 $H$. grandella males, over 28 days, and the control traps captured only 1 male $\left(\chi^{2}=15.25 \mathrm{df}=1, \mathrm{p}<0.001\right)$ 
(Figure 5 B). The results of the field experiments corroborate those obtained by the wind tunnel bioassays. Hypsipyla grandella was more attracted to quaternary solutions - Z9-14:OH; Z9,E12-14:OH; Z914:OAc, and $Z 9, E 12-14: O A c$ - than to binary solutions containing only the two major compounds Z9-14:OAc and Z9,E12-14:OAc. It is well established that in Lepidoptera minor compounds identified from female gland extracts are important to the response specificity and signal recognition in males (Linn Jr. et al., 1984; Groot et al., 2009).

The results presented here suggest that the sex pheromone blend of the studied $H$. grandella population from Southern Brazil have a different composition of those populations from other parts of the world. Therefore, they should be studied before their use for population monitoring or control in field conditions
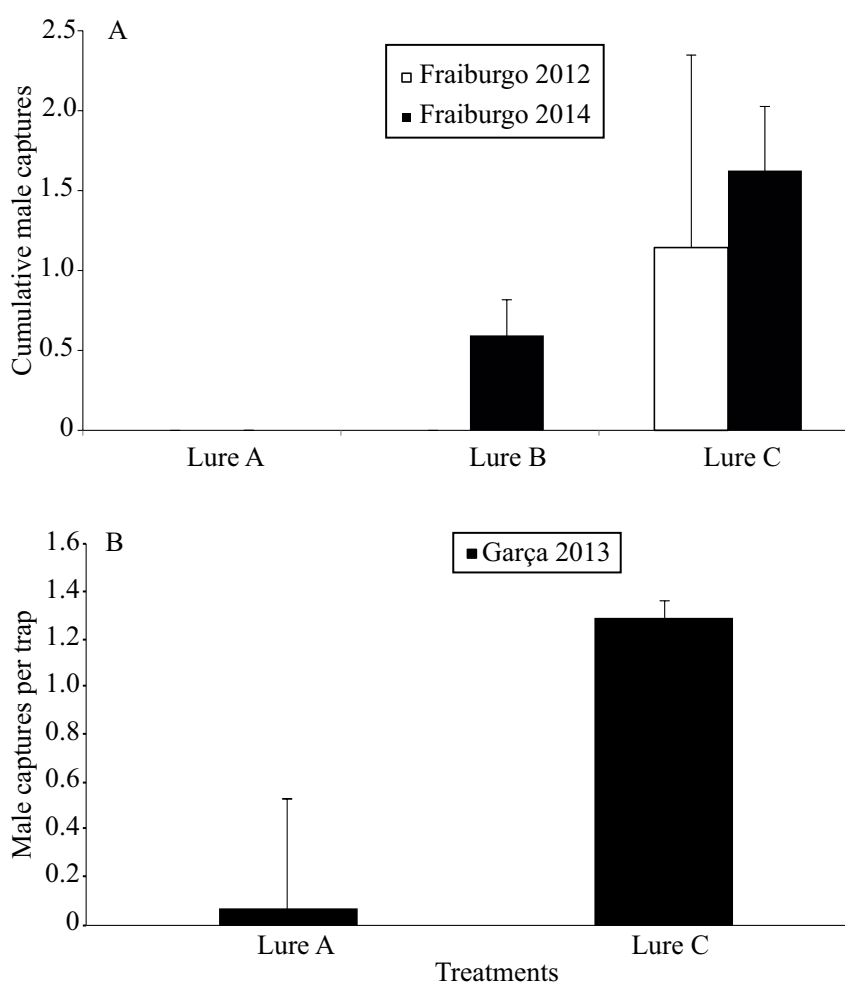

Figure 5. Mean of captures per trap of Hypsipyla grandella males, with different pheromone blends: A, field experiment conducted in Fraiburgo, SC, Brazil, during 2012 and 2014; $\mathrm{B}$, field experiment conducted in Garça, SP, Brazil, during 2013. Lure A, no pheromone; lure B, Z9-14:OAc and Z9,E1214:OAc; and lure C, Z9-14:OH, Z9,E12-14:OH, Z9-14:OAc, and $Z 9, E 12-14$ :OAc. Bars show standard error of means.
(Borek et al., 1991). Additional field experiments are required to assess the efficiency of pheromone traps to be used as a monitoring tool in the field, to evaluate the relationships between trap catch and population densities, as well as to find the best ratio and amount of the components in the baits used in traps. The identification of a correct sex pheromone blend for this species is an important step in the developing of an integrated method for $H$. grandella management aimed at the commercial production of meliaceous trees and, consequently, at the preservation of trees in natural forests.

\section{Conclusions}

1. The sex pheromone of gland of mahogany shoot borer (Hypsipyla grandella) females plays an important role in the attraction of conspecific males.

2. The female sex pheromone of $H$. grandella of a Southern Brazil population is composed at least of four components (9Z)-9-tetradecen-1-ol, (9Z,12E)9,12-tetradecadien-1-ol, (9Z)-9-tetradecenyl acetate and $(9 Z, 12 E)-9,12$-tetradecadienyl acetate; the binary, ternary, and quaternary blends of these compounds are able to attract males in laboratory experiments.

3 . The quaternary mixture is able to attract males under field conditions, which indicates that this blend has potential to aid in the field monitoring of mahogany shoot borer.

\section{Acknowledgments}

To Conselho Nacional de Desenvolvimento Científico e Tecnológico (CNPq), to Fundação de Apoio à Pesquisa do Distrito Federal (FAPDF), and to Empresa Brasileira de Pesquisa Agropecuária (Embrapa), for financial support; to $\mathrm{CNPq}$, for scholarship granted to fifth author; and to Fundação de Amparo à Pesquisa e Inovação do Estado de Santa Catarina (Fapesc, process No. 2015TR361), for a grant to fourth author.

\section{References}

ACÍN, P.; ROSEll, G.; GUERRERO, A.; QUERO, C. Sex pheromone of the Spanish population of the beet armyworm Spodoptera exigua. Journal of Chemical Ecology, v.36, p.778-786, 2010. DOI: 10.1007/s10886-010-9817-z. 
ALDRICH, J.R.; KHRIMIAN, A.; ZHANG, A.; SHEARER, P.W. Bug pheromones (Hemiptera, Heteroptera) and tachinid fly hostfinding. Denisia, v.19, p.1015-1031, 2006.

ASSIRI-BOSSON, G.; GALLOIS, M. Analyse de la sécrétion phéromonale émise par les femelles vierges de la Mineuse des pousses de l'Acajou: Hypsipyla robusta (Moore) (Lépidoptère, Pyralidae, Phycitinae). Comptes Rendus Hebdomadaires des Séances de l'Académie des Sciences. Série III: Sciences de la Vie, t.294, p.819-822, 1982.

BADEKE, E.; HAVERKAMP, A.; HANSSON, B.S.; SACHSE, S. A challenge for a male noctuid moth? Discerning the female sex pheromone against the background of plant volatiles. Frontiers in Physiology, v.7, art.143, 2016. DOI: 10.3389/fphys.2016.00143.

BATISTA-PEREIRA, L.G.; STEIN, K.; DE PAULA, A.F.; MOREIRA, J.A.; CRUZ, I.; FIGUEIREDO, M. de L.C.; PERRI JR., J.; CORREAA, A.G. Isolation, identification, synthesis, and field evaluation of the sex pheromone of the Brazilian population of Spodoptera frugiperda. Journal of Chemical Ecology, v.32, p.1085-1099, 2006. DOI: 10.1007/s10886-006-9048-5.

BLASSIOLI-MORAES, M.C.; BORGES, M.; VIANA, A.R., LAUMANN, R.A.; MIRANDA, J.E.; MAGALHÃES, D.M.; BIRKETT, M.A. Identification and field evaluation of the sex pheromone of a Brazilian population of Spodoptera cosmioides. Pesquisa Agropecuária Brasileira, v.51, p.545-554, 2016. DOI: 10.1590/S0100-204X2016000500015.

BOREK, V.; KALINOVÁ, B.; VALTEROVÁ, I.; HOCHMUT, R.; VRKOC, J. Sex pheromone gland volatiles from Hypsipyla grandella females (Lepdoptera, Pyralidae, Phycitinae). Acta Entomologica Bohemoslovaca, v.88, p.181-186, 1991.

BRUCE, T.J.A.; MIDEGA, C.A.O.; BIRKETT, M.A.; PICKETT, J.A.; KHAN, Z.R. Is quality more important than quantity? Insect behavioural responses to changes in a volatile blend after stemborer oviposition on an African grass. Biology Letters, v.6, p.314-317, 2010. DOI: 10.1098/rsbl.2009.0953.

BRUCE, T.J.A.; PICKETT, J.A. Perception of plant volatile blends by herbivorous insects - Finding the right mix. Phytochemistry, v.72, p.1605-1611, 2011. DOI: 10.1016/j.phytochem.2011.04.011.

BYERS, J.A. Modeling and regression analysis of semiochemical dose- response curves of insect antennal reception and behavior. Journal of Chemical Ecology, v.39, p.1081-1089, 2013. DOI: 10.1007/s10886-013-0328-6.

EL-SAYED, A.M. The Pherobase: Database of pheromones and semiochemicals. 2014. Available at: <www.pherobase.com>. Accessed on: Nov. 62016.

FAO. Food and Agricultural Organization of the United Nations. Global review of forest pests and diseases. Rome, 2009. (FAO Forestry Paper 156).

GOULET, E.; RUEDA, A.; SHELTON, A. Management of the mahogany shoot borer, Hypsipyla grandella (Zeller) (Lepidoptera: Pyralidae), through weed management and insecticidal sprays in 1- and 2-year-old Swietenia humilis Zucc. plantation. Crop Protection, v.24, p.812-828, 2005. DOI: 10.1016/j. cropro.2005.01.007.
GROOT, A.T.; INGLIS, O.; BOWDRIDGE, S.; SANTANGELO, R.G.; BLANCO, C.; LÓPEZ, J.D.; VARGAS, A.T.; GOULD, F.; SCHAL, C. Geographic and temporal variation in moth chemical communication. Evolution, v.63, p.1987-2003, 2009. DOI: 10.1111/j.1558-5646.2009.00702.x.

HOLSTEN, E.H.; GARA, R.I. Factors affecting pheromone production by female Hypsipyla grandella (Zeller) (Lep: Pyralidae). Environmental Entomology, v.6, p.443-446, 1977. DOI: 10.1093/ee/6.3.443.

JURENKA, R.A. Insect pheromone biosynthesis. In: SCHULZ, S. (Ed.). The chemistry of pheromones and other semiochemicals I. Berlin: Springer, 2004. p.97-132.(Topics in Current Chemistry, 239).

LAGO, J.H.G.; SOARES, M.G.; BATISTA-PEREIRA, L.G.; SILVA, M.F.G.F.; CORREAA, A.G.; FERNANDES, J.B.; VIEIRA, P.C.; ROQUE, N.F. Volatile oil from Guarea macrophylla ssp. tuberculata: Seasonal variation and electroantennographic detection by Hypsipyla grandella. Phytochemistry, v.67, p.589594, 2006. DOI: 10.1016/j.phytochem.2005.12.018.

LINN JR., C.E.; BJOSTAD, L.B.; DU, J.W.; ROELOFS, W.L. Redundancy in a chemical signal: behavioral responses of male Trichoplusia $n i$ to a 6-component sex pheromone blend. Journal of Chemical Entomology, v.10, p.1635-1658, 1984.

LUNZ, A.M.; THOMAZINI, M.J.; BLASSIOLI MORAES, M.C.; NEVES, E.J.M.; BATISTA, T.F.C.; DEGENHARDT, J.; SOUSA, L.A. de; OHASHI, O.S. Hypsipyla grandella em Mogno (Swietenia macrophylla): situação atual e perspectivas. Pesquisa Florestal Brasileira, n.59, p.45-55, 2009. DOI: 10.4336/2009. pfb.59.45.

LYNCH, R.E.; KLUN, J.A.; LEONHARDT, B.A.; SCHWARZ, M.; GARNER, J.W. Female sex pheromone of the lesser cornstalk borer, Elasmopalpus lignosellus (Lepidoptera: Pyralidae). Environmental Entomology, v.13, p.121-126, 1984. DOI: 10.1093/ ee/13.1.121.

NIST Livro de Química na Web: Base de dados de Referência padrão do NIST número 69. Available: <http://webbook.nist.gov/ chemistry/>. Accessed on: Nov. 62016.

NIST. National Institute of Standards and Technology. NIST/ EPA/NIH Mass Spectral Library (NIST 08) and NIST Mass Spectral Search Program (Version 2.0f) for use with Microsoft Windows: user's guide. 2008. Gaithersburg: NIST, 2008. (NIST Standard reference database 1A). Available at: $<$ http://www.nist.gov/srd/upload/Ver20Man.pdf $>$. Accessed on: Feb. 102016.

PLATH, M.; MODY, K.; POTVIN, C.; DORN, S. Establishment of native tropical timber trees in monoculture and mixed-species plantations: Small-scale effects on tree performance and insect herbivory. Forest Ecology and Management, v.261, p.741-750, 2011.

R CORE TEAM. R: a language and environment for statistical computing. Viena: R Foundation for Statistical Computing, 2012.

ROUYAR, A.; DEISIG, N.; DUPUY, F.; LIMOUSIN, D.; WYCKE, M.-A.; RENOU, M.; ANTON, S. Unexpected plant odor responses in a moth pheromone system. Frontiers in Physiology, v.6, art.148, 2015. DOI 10.3389/fphys.2015.00148. 
SCHMIDT, F.G.V.; MONNERAT, R.G.; BORGES, M.; CARVALHO, R. da S. Metodologia de criação de insetos para avaliação de agentes entomopatogênicos. Brasília: Embrapa Recursos Genéticos e Biotecnologia, 2001. (Embrapa Recursos Genéticos e Biotecnologia. Circular técnica, 11).

TEAL, P.E.A.; MITCHELL, E.R.; TUMLINSON, J.H.; HEATH, R.R; SUGIE, H. Identification of volatile sex pheromone components released by the southern armyworm, Spodoptera eridania (Cramer). Journal of Chemical Ecology, v.11, p.717-725, 1985.

VON ARX, M.; SCHMIDT-BÜSER, D.; GUERIN, P.M Host plant induce oriented flight behaviour in male European grapevine moths, Lobesia botrana. Journal of Insect Physiology, v.57, p.1323-1331, 2011. DOI: 10.1016/j.jinsphys.2011.06.010.

WITZGALL, P.; KIRSCH, P.; CORK, A. Sex pheromones and their impact on pest management. Journal of Chemical Ecology, v.36, p.80-100, 2010. DOI: 10.1007/s10886-009-9737-y.

ZHANG, J.-P.; SALCEDO, C.; FANG, Y.-L.; ZHANG, R.-J.; ZHANG, Z.-N. An overlooked component: (Z)-9-tetradecenal as a sex pheromone in Helicoverpa armigera. Journal of Insect Physiology, v.58, p.1209-1216, 2012. DOI: 10.1016/j. jinsphys.2012.05.018.

Received on June 14, 2016 and accepted on April 13, 2017 